\title{
Expression of PPAR $\gamma$ is reduced by medium supplementation with L-glutamine in human colorectal Caco-2 cells
}

\author{
CATHY FIATTE $^{1,2}$, CÉCILE HUIN ${ }^{2}$, PHILIPPE COLLET ${ }^{2}$, \\ FRANÇOIS PLÉNAT ${ }^{3}$, MICHEL DAUÇA ${ }^{2}$ and HERVÉ SCHOHN ${ }^{1}$
}

\begin{abstract}
${ }^{1}$ Laboratoire d'Ingénierie Moléculaire et Biochimie Pharmacologique, EA 3940, Université P. Verlaine, Metz, Campus Bridoux, F57070 Metz; ${ }^{2}$ Laboratoire de Biologie Cellulaire du Développement, EA 3446

'Proliférateurs de Peroxysomes', Faculté des Sciences et Techniques, Université Henri Poincaré, Nancy 1, Boulevard des Aiguillettes, BP 239, F54506; ${ }^{3}$ Laboratoire d'Anatomie et de Cytologie Pathologique, CHRU Nancy Brabois, Avenue du Morvan, F54505 Vandoeuvre les Nancy, France
\end{abstract}

Received May 5, 2008; Accepted August 18, 2008

DOI: 10.3892/ijmm_00000091

\begin{abstract}
Peroxisome proliferator-activated receptor- $\gamma$ (PPAR $\gamma$ ) belongs to the nuclear hormone receptor family. This receptor is implicated in colon cell differentiation and in colon cancer. Receptor activation by specific agonists has been shown to protect against colon cancer progression. PPAR $\gamma$ protein content within cells is modulated by several mechanisms, including proteasome degradation, activation of Wnt signalling pathways and presence of fermentation products such as butyrate. Herein, we investigated the impact of L-glutamine on PPAR $\gamma$ expression during the differentiation of Caco-2 cells grown in medium containing dialyzed fetal calf serum supplemented or not with L-glutamine. Using RTPCR and Western blotting, we demonstrated that PPAR $\gamma$ expression was decreased when L-glutamine was added to the medium. Using immunohistochemistry, we demonstrated that PPAR $\gamma$ immunostaining was mainly found in cytoplasm when cells were cultured with L-glutamine while it was found in nuclei and cytoplasm when cells were grown without the addition of L-glutamine. Supershift retardation assays demonstrated a decrease of PPAR $\gamma$ binding onto consensus peroxisome proliferator response element. We concluded that L-glutamine modulated PPAR $\gamma$ expression in Caco- 2 cells.
\end{abstract}

Correspondence to: Dr Hervé Schohn, Laboratoire d'Ingénierie Moléculaire et Biochimie Pharmacologique, EA 3940, Université P. Verlaine, Metz, Campus Bridoux, F57070 Metz, France

E-mail: schohn@univ-metz.fr

Abbreviations: DMEM, Dulbecco's minimum essential medium; DPBS, Dulbecco's phosphate buffer; dFCS, dialysed fetal calf serum; FCS, fetal calf serum, GAPDH, glyceraldehyde 3phosphate deshydrogenase, KGA, kidney-type glutaminase; LGA, liver-type glutaminase, PPAR, peroxisome proliferator-activated receptor

Key words: Peroxisome proliferator-activated receptor, colon, cell differentiation, L-glutamine, colon adenocarcinoma cell-line

\section{Introduction}

Peroxisome proliferator activated receptor- $\gamma(\operatorname{PPAR} \gamma)$ belongs to the nuclear hormone receptor family (NHR). After ligand activation, PPAR $\gamma$ forms heterodimers with the 9-cis retinoid receptor which bind on a specific DNA sequence, named peroxisome proliferator response element (PPRE), localized in the promoter of target genes (1).

In the gastrointestinal tract, PPAR $\gamma$ expression increases concomitantly with cell differentiation either along the intestine crypt villi axis or in colon tubular glands (2-4). Drori et al demonstrated that PPAR $\gamma$ is implicated in cell lineage in association with coactivator Hic-5 (5). In contrast, PPAR $\gamma$ is involved in the development of colon tumours, but its role is still debated (6). In many human colon cell types, activation of PPAR $\gamma$ by agonist leads to growth arrest, differentiation and/or anoikis by regulating the transcription of several target genes involved in the cell cycle control (1). In contrast, in vivo experiments using rodent models showed pro-tumoral properties $(7,8)$.

L-glutamine (GLN) is the most abundant amino acid in the body. The circulating concentration of GLN (0.6-0.9 mmol/l) is maintained at a constant level (9) and depends on the rate of GLN uptake and release by the various organs in the body (10). Following uptake, GLN is converted to glutamate and ammonia by glutaminase in the mitochondria. There are two different glutaminases, liver- (LGA) and kidney- (KGA) type glutaminase $(11,12)$. It has been demonstrated that the two isoforms are present in colon adenocarcinoma derived cell lines (13). In addition, a third isoform named CGA has been identified (12). GLN conversion provides substrates for energy production, for nucleotide or protein biosynthesis and metabolic intermediates. There is a direct correlation between glutaminase activity and GLN consumption and growth rates (14). GLN and diglycerol acids, such as butyrate, are the main fuel for intestinal and colon cell metabolism $(15,16)$. Studies have outlined the potential functions of GLN on intestine and colon-derived cells. In porcine IPEC-J2 and in rat intestine crypt-derived IEC-6 cells, supplementation with GLN stimulates cell proliferation (17). Similar results were 
obtained using human colon-derived cells as HT29 and Caco-2 cells (18). GLN supplementation also modulates the phenotype of human colon cell models with decreases of specific cell markers in a dose-dependent manner (19).

It was shown that butyrate increased PPAR $\gamma$ expression via independent mechanisms $(20,21)$. We hypothesized that GLN also modulates PPAR $\gamma$ expression in colon cells. Herein, we studied the effects of GLN on PPAR $\gamma$ expression in Caco-2 cells as a model for absorptive cells (22). Cells were grown either in a medium containing dialysed fetal calf serum or in a control culture medium. We demonstrated that GLN supplementation reduced the expression of PPAR $\gamma$ at the transcriptional and protein levels. Using immunohistochemistry, we observed that PPAR $\gamma$ stained mainly in the cytoplasm when GLN was added to the medium. Shift and supershift retardation assays carried out with nuclear extracts prepared from cells grown in GLN enriched medium demonstrated a reduced PPAR $\gamma$ binding to consensus PPRE.

\section{Materials and methods}

Reagents. Dulbecco's modified Eagle's minimum medium (DMEM), trypsin/EDTA solution, non-essential amino acids solution, Dulbecco's modified sodium phosphate buffer (DPBS) and fetal calf serum (FCS) were purchased from Eurobio (Les Ulis, France). Taq polymerase, RNAsine, reverse transcriptase (M-MLV) and primers were obtained from Invitrogen Corporation (Paisley, Scotland). DialysedFCS was purchased from Hyclone (Perbio, Belgium). BM Chemiluminescence Western blot kit revelation was purchased from Roche (Mannheim, Germany). We used different rabbit polyclonal antibodies directed against PPAR $\gamma$. For Western blotting, we used anti-PPAR $\gamma$ polyclonal rabbit antibodies purchased from Cayman Chemicals (Interchim, Montluçon, France). For immunohistochemistry, polyclonal rabbit antibodies against PPAR $\gamma$ were obtained from AB Reagent (Golden, CO, USA). Polyclonal rabbit antiserum against common NH2-terminal sequence of each PPAR isotype (panPPAR antiserum) were prepared as described (23). Polyclonal rabbit antibodies solution directed against glyceraldehyde 3-phosphate dehydrogenase (GAPDH) was from Chemicon-Millipore (Molsheim, France). Other reagents were of analytical grade.

Cell culture. Caco-2 cell line was a generous gift from M. Rousset (Inserm U505, Paris, France). Caco-2 cells were grown in DMEM-25 mM glucose containing 20\% (v/v) either heat-inactivated FCS (control medium) or dialysed FCS (dFCS-medium) and 1\% (v/v) non-essential amino acids; media were supplemented with increasing concentrations of glutamine up to $4 \mathrm{mM}$. Starting seeding was $6 \times 10^{4}$ cells $/ \mathrm{ml}$. Cells were cultured in $5 \% \mathrm{CO}_{2}$ in a constant humidified atmosphere. Medium was changed daily $48 \mathrm{~h}$ after seeding until achieving 5,10 and 15 days in culture. Cells were washed twice with cold DPBS for $5 \mathrm{~min}$. Cell layers were stored at $-80^{\circ} \mathrm{C}$ until used.

Determination of enzyme specific activities. Frozen cell layers were scraped using a rubber policeman in $500 \mu 1$ of ice-cold 0.1 M potassium phosphate buffer $(\mathrm{pH}$ 7.1) and homogenised. Cell extracts were assayed for protein concentration according to Bradford (24) using bovine serum albumin as a standard. Total glutaminase (EC.5.3.1.2) activities were quantified according to Collins et al (25) from the initial procedure already described (26). Alkaline phosphatase (AP, EC 3.1.3.1) activities were determined according to Garen and Levinthal (27). One unit of enzyme activity was defined as the activity which hydrolyses $1 \mu \mathrm{M}$ of substrate per min at $37^{\circ} \mathrm{C}$ under the experimental conditions.

Western blotting. Protein homogenates were prepared from cell layers in Hepes/ $\mathrm{KCl}$ buffer according to Mansen et al (4). Protein $(25 \mu \mathrm{g})$ was resolved in $10 \%$ SDS-PAGE (28), then transferred onto PVDF membranes (29) and further exposed to chemiluminescence reagent according to the manufacturer's protocol (Roche). We used polyclonal rabbit antiserum directed against PPAR $\gamma(1: 1,1000)$ as described previously (30) and monoclonal antibodies against GAPDH $(1: 5,000)$. The intensities of PPAR $\gamma$ bands were quantified (Gel Doc, BioRad, Marne-la Coquette, France). Results are expressed in arbitrary units.

Immunohistochemistry. The procedure was previously described in detail (2). Briefly, 5 and 15 day-old cell layers were washed twice with cold DPBS and fixed in PBS containing $4 \%(\mathrm{v} / \mathrm{v})$ formaldehyde overnight at $4^{\circ} \mathrm{C}$. Cell layers were scraped with a rubber policeman, centrifuged at $4^{\circ} \mathrm{C}$ for $5 \mathrm{~min}$ at $1,000 \mathrm{x} \mathrm{g}$. The pellets were embedded in paraffin. Sections $(5 \mu \mathrm{m})$ were prepared as described previously (2).

RT-PCR analysis. Total RNA was phenol/chloroformextracted (31). RT-PCR reaction was carried out from standard protocol using $1 \mu \mathrm{g}$ of total RNA and $200 \mathrm{U}$ of reverse transcriptase (M-MLV) for $2 \mathrm{~h}$ at $37^{\circ} \mathrm{C}$. cDNA amplification was carried out in $20 \mathrm{mM}$ Tris/ $\mathrm{HCl}(\mathrm{pH} \mathrm{8.4)}$ buffer containing $50 \mathrm{mM} \mathrm{KCl}, 1.5 \mathrm{mM} \mathrm{MgCl}_{2}, 5 \mathrm{U}$ of RNAsine, $0.2 \mu \mathrm{M}$ dNTP, $0.4 \mu \mathrm{M}$ each selected primer up and down, $2 \mu \mathrm{l}$ of RT sample and $2.5 \mathrm{U}$ of Taq polymerase for 26-32 cycles $\left(95^{\circ} \mathrm{C}\right.$, $30 \mathrm{sec}$; Tm of primers annealing, $30 \mathrm{sec}$; $72^{\circ} \mathrm{C}, 30 \mathrm{sec}$ ) followed by an extension step at $72^{\circ} \mathrm{C}$ for $5 \mathrm{~min}$. PCR primers used are listed in Table I. PCR products $(10 \mu \mathrm{l})$ were analysed on $2 \%(\mathrm{w} / \mathrm{v})$ TBE-agarose gels. The intensities of the obtained bands were quantified. Results are expressed as the ratio (gene of interest/GAPDH) in arbitrary units.

Electrophoretic mobility shift and super-shift assays. 15 dayold Caco-2 cells were used. Cells were grown in a control medium and in the same medium supplemented with $20 \%$ (v/v) dialysed FCS and $2 \mathrm{mM}$ glutamine. Nuclear extracts were prepared (32). Nuclear proteins $(10 \mu \mathrm{g})$ were used to perform supershift assays as previously described in detail (33). Supershifts were obtained using rabbit antiserum against $\mathrm{COOH}$-amino acid sequence (pan-PPAR) and rabbit antiserum against PPAR $\gamma$ prepared as described (23).

Statistics. A comparison of the variation of mRNA transcript contents along cell culture duration was tested by one way ANOVA performed with Bonferroni post-hoc test for the multiple comparisons. Differences were considered significant at $\mathrm{P} \leq 0.05$. 
Table I. Primer sequences used in this study.

\begin{tabular}{|c|c|c|c|}
\hline Primer name & Primer sequence ( $5^{\prime}$ to $\left.3^{\prime}\right)$ & Primer length (nt) & Product length (bp) \\
\hline PPAR $\alpha$ up & $\begin{array}{l}\text { ATGGTGGACACGGAAAGCCCACTCTG } \\
\text { ССССТСТССССАСТ }\end{array}$ & 40 & 385 \\
\hline $\operatorname{PPAR} \alpha$ down & $\begin{array}{l}\text { TTCGCCGAAAGAAGCCCTTGCAGCCT } \\
\text { TCACA }\end{array}$ & 31 & \\
\hline PPARß up & TGTGAGGGGTGCAAGGGCTTCTTCCG & 26 & 560 \\
\hline PPARß down & GGTGGTTGAGGAAGAGGGTGCTGAA & 25 & \\
\hline PPAR $\gamma$ up & TCATGCTTGTGAAGGATGCAAGG & 23 & 759 \\
\hline $\operatorname{PPAR} \gamma$ down & TCCAGTGCATTGAACTTCACAGC & 23 & \\
\hline KGA up & CCCGTTGTCAGAATCTCCTTGAGG & 24 & 680 \\
\hline KGA down & TGATGGCTGCGACACTGGCTAATG & 24 & \\
\hline LGA up & GTGCTCGGAAGTTAGACCCACG & 22 & 464 \\
\hline LGA down & СTCTTTGGACAGGGCCTCAGCT & 22 & \\
\hline CGA up & GATGTCCTCATTTGACTCAGGTGAC & 25 & 383 \\
\hline CGA down & TGATGGCTGCGACACTGGCTAATG & 24 & \\
\hline GAPDH up & GACСССТTCATTGACСТCAАCTACATG & 27 & 446 \\
\hline GAPDH down & GCTGTGATGGCATGGACTGTGGTCAT & 26 & \\
\hline
\end{tabular}

\section{Results}

Caco-2 cells were cultured in control and in dSVF-medium. The concentration of free GLN was $0.56 \mathrm{mM}$ and $0.02 \mathrm{mM}$ in the respective medium. Caco-2 cell growth was not altered using dSVF-medium. The addition of $2 \mathrm{mM}$ GLN had a slight impact on cell growth (Fig. 1a). In contrast, the addition of $1 \mathrm{mM}$ GLN in control medium increased cell growth rate $\sim 2$ fold. Nevertheless, cells achieved confluence between 7 and 10 days regardless of the media used. AP activities were determined in homogenates from Caco- 2 cells cultured during 5,10 or 15 days in either media supplemented with GLN. As shown in Fig. 1b, AP activities were raised to a maximum after 15 days. Greater AP activities were obtained when cells were cultured in dFCS-medium with $1 \mathrm{mM}$ GLN or in the control medium with $2 \mathrm{mM}$ GLN. The latter corresponds to GLN concentration used in a routinely cultured condition for these cells. With $2 \mathrm{mM}$ GLN in dFCS-medium, AP activities were almost 2-fold lower than those determined in homogenates from cells cultured in dFCS-medium containing $1 \mathrm{mM}$ GLN. Similar results were also obtained when cells were grown in the same medium supplemented with $4 \mathrm{mM} \mathrm{GLN} \mathrm{(not}$ shown). In contrast, no major change was observed for total glutaminase activities determined in homogenates from cells cultured either with control medium or with dFCS-medium containing $1 \mathrm{mM}$ GLN. The highest glutaminase activities were obtained when cells were grown in either medium supplemented with $2 \mathrm{mM}$ GLN. Our results suggested therefore that the use of dFCS-medium altered neither cell growth nor differentiation processes occurring spontaneously in Caco-2 cells (22). The addition of GLN improved cell proliferation and differentiation processes as evidenced by the determination of AP activity as a marker of Caco- 2 cell differentiation. However, these effects were largely dependent on the GLN concentration used. Collectively, similar results were obtained when cells were cultured in dFCS-medium supplemented with 1 or $2 \mathrm{mM} \mathrm{GLN}$ or control medium without GLN. In these cell culture conditions, we thought it of use to study glutaminase expression since KGA and LGA are present in colorectal cells, and to investigate if GLN can modulate respective glutaminase expression. The three isoforms namely KGA, CGA and LGA were present in Caco-2 cells (Fig. 2d) but their respective mRNA levels varied according to GLN supplementation as compared to control medium (Fig. 2a-c). There were however, no dramatic alterations at the transcriptional level for each isoform and it is likely that glutaminase mRNA transcripts stayed constant upon culture delay even though KGA mRNA levels were increased 2-fold when Caco-2 cells were grown in dFCSmedium with 2 mM GLN (Fig. 2a). In brief, KGA expression was low regardless of the culture conditions used (Fig. 2a and d). CGA mRNA were abundant when cells were grown in the control medium and decreased in a dose-dependent manner when cells were cultured in dFCS-medium supplemented with GLN (Fig. 2b and d). Finally, LGA was mainly expressed in cells grown in dFCS-medium supplemented with $1 \mathrm{mM}$ GLN whereas mRNA levels were quite similar in the other culture conditions tested (Fig. 2c and d). Thus, our results suggested that GLN supplementation accounted for the observed alteration of glutaminase isoform mRNA levels.

Similarly, we quantified PPAR isotype mRNA content by semi-quantitative RT-PCR (Fig. 3). Our results showed that no major change was observed for PPAR $\alpha$ or $\beta$ mRNA levels regardless of the cell culture conditions. PPAR $\alpha$ mRNAs increased between 5 and 15 days ( $\leq 2$-fold) whereas PPARß 

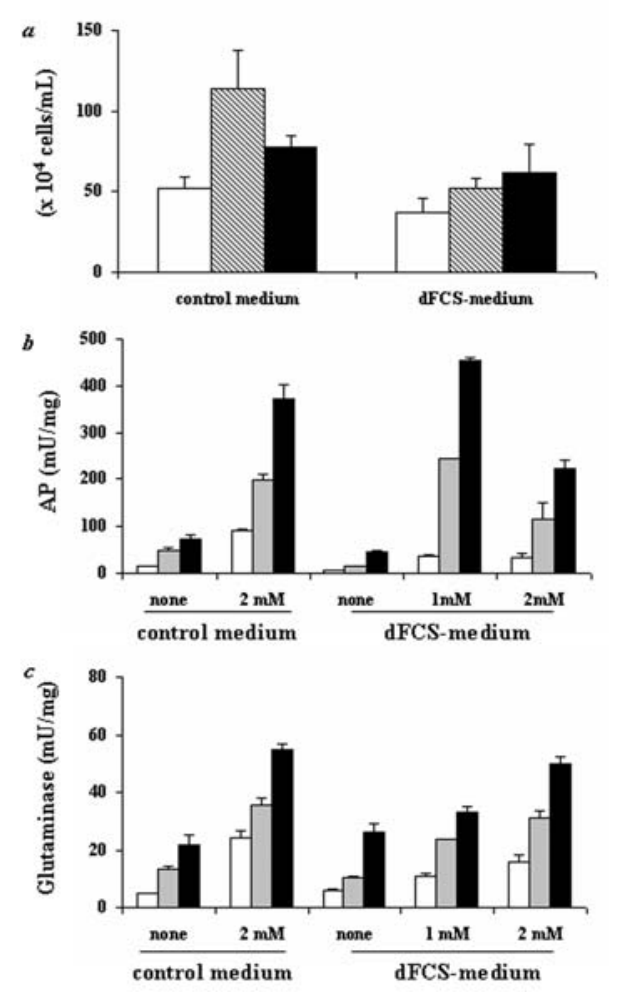

Figure 1. Impact of GLN supplementation on Caco-2 cell growth and differentiation. (a) Caco-2 cells were grown for 5 days in a control medium or a dFCS-medium in the absence (white) or in the presence of $1 \mathrm{mM}$ (hatched) or $2 \mathrm{mM}$ (black) GLN. Cells were numbered with trypan blue. Cell counts are expressed as a mean \pm SD $(n=3)$. (b) Alkaline phosphatase (AP) activities were determined in homogenates from 5 (white boxes), 10 (grey) or 15 day-old cells (black) grown in media containing GLN. (c) Total glutaminase specific activities determination as described in (b) for AP. Specific activities are expressed as mean \pm SD of three independent experiments.

mRNA content was slightly modified. In contrast, PPAR $\gamma$ transcripts were 2-fold lower in cells grown with dFCS-medium with or without GLN. In all cases, PPAR $\gamma$ mRNA levels were higher at 15 days as compared with those at 5 days. A 2- and 2.6-fold increase was obtained when cells were grown in dFCS-medium containing 1 or $2 \mathrm{mM}$ GLN, respectively. Our results suggest therefore that the impact of GLN is closely restricted to PPAR $\gamma$ isotype.

We investigated whether the PPAR $\gamma$ protein level was modifiable in the presence of GLN and whether the receptor content correlated with the mRNA level changes observed with each cell medium. As shown in Fig. 4b, PPAR $\gamma$ levels increased 2-fold upon culture delay when Caco-2 cells were cultured in the control medium. In contrast, PPAR $\gamma$ expression was high at 5 days of culture and decreased thereafter with the addition of $2 \mathrm{mM} \mathrm{GLN}$ in this medium (2.5-fold decrease) or using dFCS-medium supplemented with 1 or $2 \mathrm{mM} \mathrm{GLN}$ (2.7- and 1.6-fold decrease, respectively). Thus, our results demonstrated that GLN supplementation reduced PPAR $\gamma$ protein content and an inverse correlation can exist between PPAR $\gamma$ mRNA and protein levels. We postulated that these changes may reflect modifications within the cells and reduce PPAR $\gamma$ binding capacity on PPRE. Thus, using immunohistochemistry, we observed that PPAR $\gamma$ was found

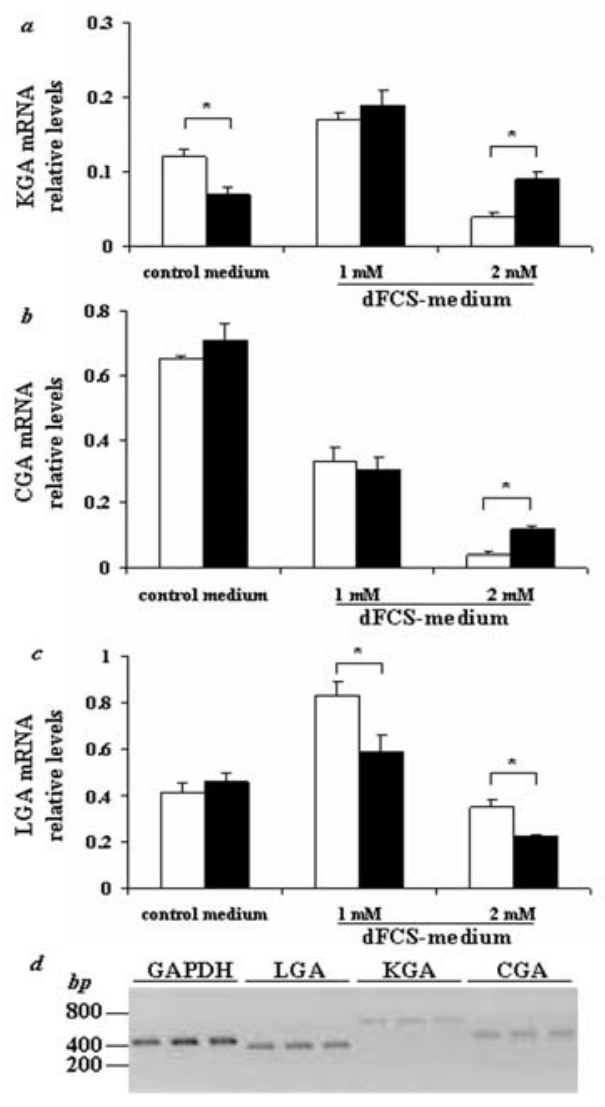

Figure 2. Glutaminase mRNA levels in Caco-2 cells grown in the presence of GLN. RT-PCR experiment was performed starting with $1 \mu \mathrm{g}$ of total RNA and specific primers respectively designed from KGA (a), CGA (b) and LGA (c) gene. PCR products were resolved in a $2 \%(\mathrm{w} / \mathrm{v}) \mathrm{TBE}$ agarose gel and quantified. mRNA quantification was carried out with total RNA extracted from cells grown during 5 (white) or 15 days (black) in media containing GLN. The bar graphs represent the mean \pm SD of three independent experiments. Significant differences at P-value $\leq 0.05$ are shown (ANOVA). (d) Glutaminase mRNA expression in Caco-2 cells. PCR products were resolved in a $2 \% \mathrm{TBE}$ agarose gel. Typical results obtained after amplification was carried out with total RNA extracted from cells grown in control medium during 15 days. GAPDH was used as an internal control.

mainly in the cytoplasm of 5 (not shown) or 15 day-old Caco-2 cells cultured in dFCS-medium with GLN (Fig. 5b and d) whereas PPAR $\gamma$ was mainly localised in the nuclei of cells grown in the control medium (Fig. 5e) although positive signals were also observed in the cytoplasm. Gel retardation assays were performed with nuclei extracts prepared from Caco-2 cultured in control medium or dFCS-medium containing $2 \mathrm{mM}$ GLN (Fig. 6). Using pan PPAR or PPAR $\gamma$ antibodies (23), supershift complexes were obtained demonstrating that PPAR $\gamma$ binds to consensus PPRE. However, when nuclei extracts from cells cultured in medium containing GLN were used, shift complexes were less abundant compared with those prepared from control cells (Fig. 6).

\section{Discussion}

GLN is usually added to cell culture medium since this amino acid is needed to facilitate the proliferation of tumour cells in vitro (25). In the intestine and, to a lesser extent, in the colon, GLN is an important nutriment for epithelial and 

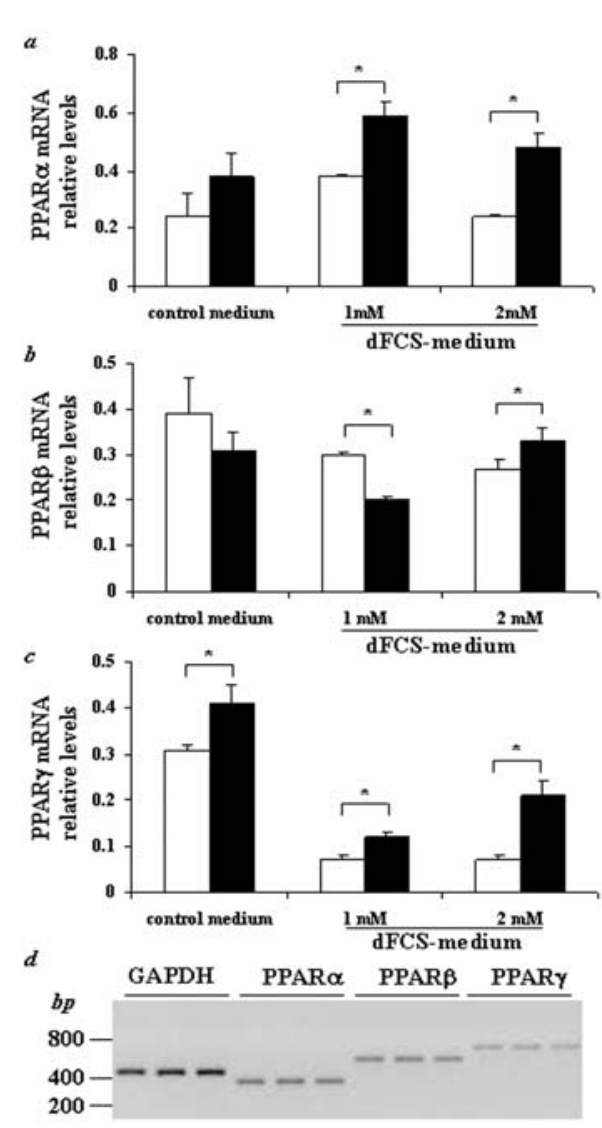

Figure 3. PPAR transcript levels in Caco-2 cells grown in the presence of GLN. RT-PCR experiment was performed starting with $1 \mu \mathrm{g}$ of total RNA and specific primers respectively designed from PPAR $\alpha$ (a), PPARß (b) and $\operatorname{PPAR} \gamma$ (c) gene from cells grown during 5 (white) or 15 days (black) in media containing GLN. The bar graphs represent the mean $\pm \mathrm{SD}$ of three independent experiments. Significant differences at P-value $\leq 0.05$ are shown (ANOVA). (d) PPAR mRNA expression in Caco-2 cells. PCR products were resolved in a $2 \% \mathrm{TBE}$ agarose gel. Typical results obtained after amplification was carried out with total RNA extracted from cells grown in control medium during 15 days. GAPDH was used as an internal control.

immune cells (34). Using colorectal cells as models, several studies provide evidence that GLN supplementation increases cell growth $(17,18)$ and decreases protein marker activities or levels associated to the differentiation process usually observed in such cell lines (19). GLN has also an antiapoptotic effect. For example, GLN depletion alone induced apoptosis (35). GLN protected cells to heat shockinduced apoptosis (36). Using HT29 cells, Evans et al (37) demonstrated that TRAIL-induced apoptosis was inhibited with GLN, at a dose of $0.5 \mathrm{mM}$ which is in the range of GLN concentrations found in human plasma. Herein, Caco-2 cells adapted in GLN depleted medium had similar growth to those grown in a control medium. We observed neither a major change of the growth rate or in the alkaline phosphatase activities compared to the cells grown in the control medium (Fig. 1b). Enzyme activities were low compared to those obtained with cells grown in GLN-enriched media, suggesting that GLN at low concentration is needed for the differentiation process of Caco-2 cells.
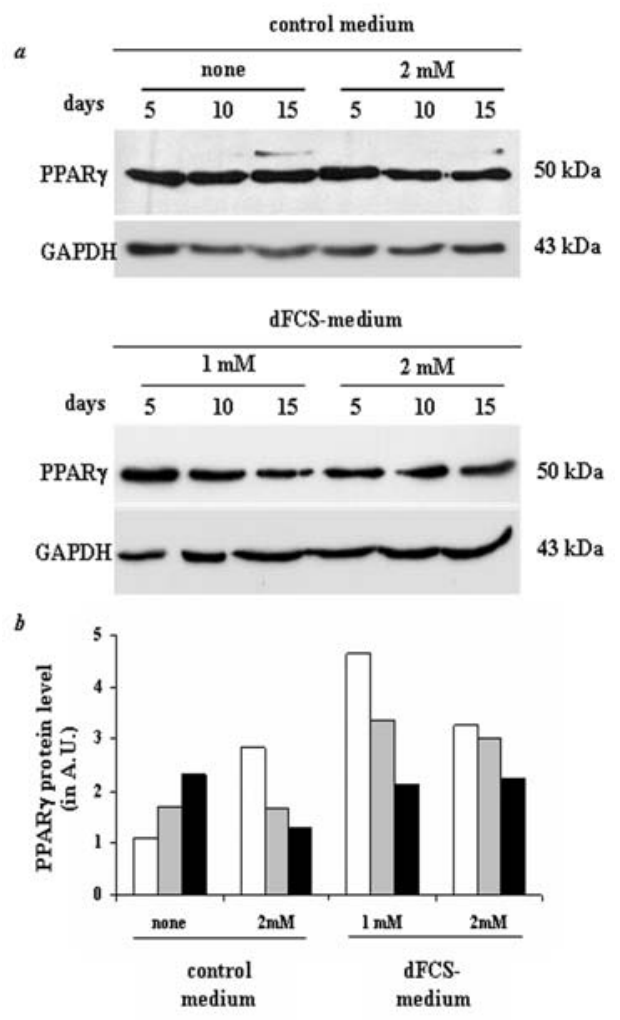

Figure 4. PPAR $\gamma$ protein content in Caco-2 cells grown in the presence of GLN. (a) Protein homogenates were prepared from cells cultured during 5 (white), 10 (grey) or 15 days (black) in media containing GLN. Proteins $(25 \mu \mathrm{g})$ were submitted to Western blot analysis as described in Materials and methods section. Data are from at least three independent experiments. (b) Relative expression of PPAR $\gamma$ content quantified from the blots presented in (a) as described in the Materials and methods section.

We demonstrated that KGA/CGA and LGA are present in HT29 cells. The mRNA levels of KGA and CGA remained constant in Caco-2 cells during culture delay. In contrast, LGA mRNA isoform decreased at a dose-dependent manner. Our results extended previous studies in the field demonstrating the presence of glutaminase isoforms in colorectal cells (13). However, little information has been provided on the expression of glutaminase in colon or intestine epithelial cells or in colon cancer. Higher glutaminase activities were found in human intestine than in colon tissues (38). In colonic polyps, GLN content and glutaminase activities were lower than in normal-paired tissues (39). Our results suggested that the transcriptional levels of each isoform may be regulated differently in the presence of GLN.

Recent studies outlined the role of either GLN or PPAR $\gamma$ and the possible link between PPAR $\gamma$ expression and enteral nutrition supplemented with GLN. These are involved in the protection against inflammatory diseases or mucosa injury. In the colon, particularly in ulcerative colitis, ligandactivated PPAR $\gamma$ reduced inflammatory gene expression in epithelial and immune cells but this protective effect is also though to occur independently of PPAR $\gamma$ activation (40-42). Sido et al demonstrated a decrease in GLN content which is associated with a loss of glutaminase activity in the ileum of patients suffering from Crohn's disease (43). Using a rat model 


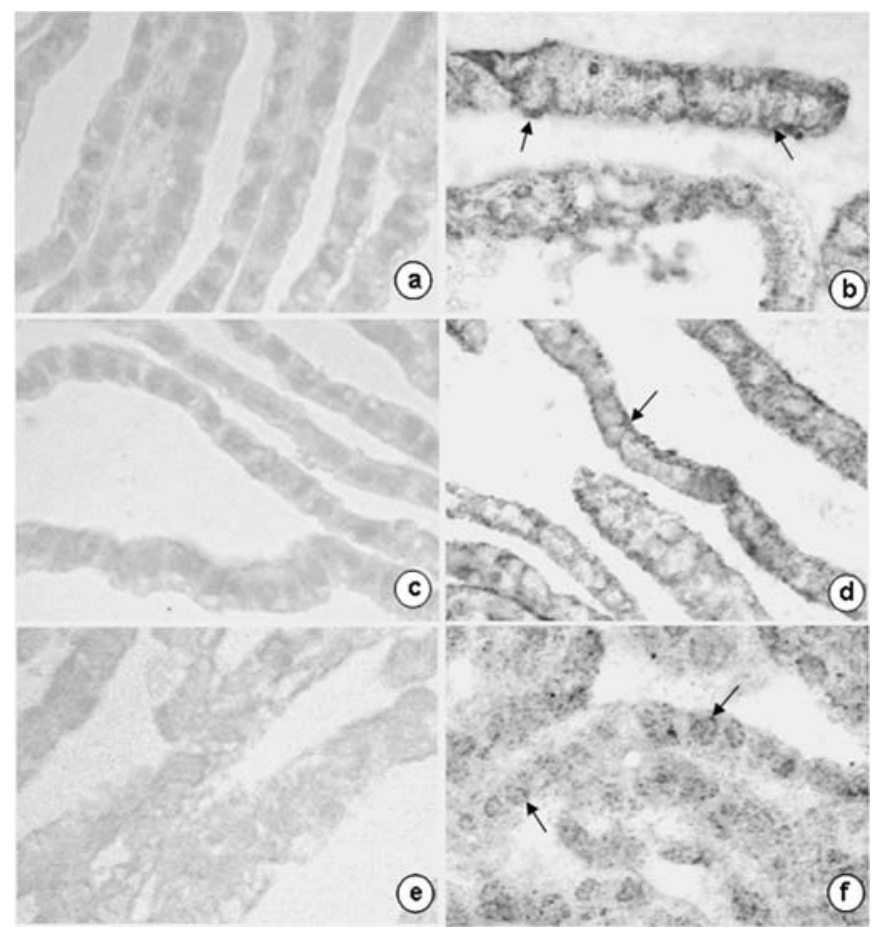

Figure 5. Immunodetection of PPAR $\gamma$ within Caco-2 cells. Caco-2 cells were grown during 15 days in dFCS-medium containing 1 ( $a$ and $b$ ) or $2 \mathrm{mM}$ (c and d) of GLN or in control medium (e and f). Cell layers were harvested and embedded in paraffin. Thick sections $(5 \mu \mathrm{m})$ were prepared for immunohistochemistry using commercial anti PPAR $\gamma$ rabbit polyclonal antibodies and using the procedure described previously (2). Sections were finally counterstained with hematoxylin/safran coloration (a, c and e). (Magnification x 400) PPAR $\gamma$ immunostaining is indicated by arrows (in b, d and $f$ ).

of gut ischemia/reperfusion, it was demonstrated that enteral GLN has a protective effect against inflammation and injury which are increased by arginine via the induction of inductible nitric oxide synthase (44). This protective effect was abrogated in the presence of GW 9662, an antagonist of PPAR $\gamma$ activation. PPAR $\gamma$ protein content was increased with GLN and decreased with arginine. In addition, PPAR $\gamma$ has a protective role against gut cyclooxygenase-2-induced inflammation which is reverted by selective inhibitor NS-398 (45). We demonstrated herein that the addition of GLN decreased PPAR $\gamma$ expression in Caco- 2 cells at the transcriptional and protein levels (Figs. 3 and 4). In contrast, we showed that PPAR $\gamma$ expression increased with spontaneous differentiation of Caco-2 cells when cells are cultured in control medium (Fig. 4). These results are similar to previous data obtained in vitro $(2,3)$ or in vivo in human and rodent $(4,7,23)$. However, the addition of GLN in the medium lowered PPAR $\gamma$ protein content but had no effect at mRNAs, suggesting that GLN impact may involve the regulation of receptor translation since PPAR $\gamma$ protein achieved similar levels when cells were grown in medium containing GLN (Fig. 4). The mechanisms of PPAR $\gamma$ regulation by GLN are unknown to date. Sato et al (44) claimed that GLN may be a ligand of PPAR $\gamma$ but further studies are needed to confirm this hypothesis. As shown in Fig. 5, PPAR $\gamma$ remained in the cytoplasm when Caco-2 cells were cultured in GLNsupplemented media and as a consequence PPAR $\gamma$ binding to

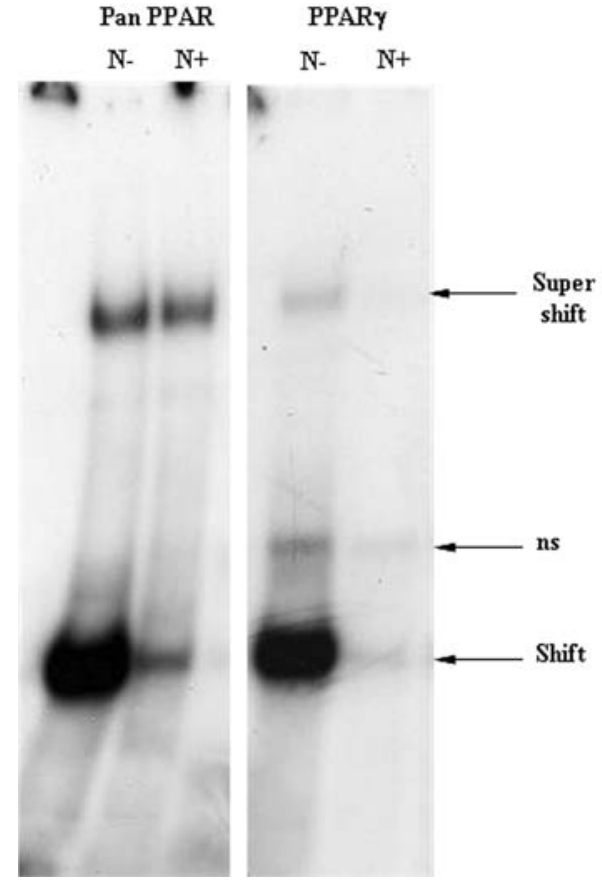

Figure 6. Electrophoretic mobility shift assays for PPAR $\gamma$ isotype. Nuclear protein extract were prepared from Caco- 2 cells cultured in a control medium $(\mathrm{N}-)$ or in a dFCS- medium containing $2 \mathrm{mM}$ GLN (N+). Gel retardation assays were carried out as described in the Materials and methods section. Shift and supershift are represented by arrows (ns, non specific binding).

consensus PPRE was decreased (Fig. 6). A cytoplasmic localisation of the receptor is associated with inactive PPAR $\gamma$ in several cancer samples $(3,46-49)$. It is expected that GLN inhibits receptor translocation to the nucleus by increasing receptor phosphorylation which reduces PPAR $\gamma$ independent transactivation at the receptor A/B domain $(50,51)$. Several studies also indicated a possible link between the phosphorylation process and GLN. For example, Rhoads et al $(17,52)$ demonstrated in rat intestinal crypt cells that GLN enhanced phosphorylation of target protein via MAPK kinase independently of Raf and JNK kinase pathway activation. This effect is associated with increasing cell proliferation. In human colon adenocarcinoma WiDr and hepatoma cells, phorbol esters inhibit the protein kinase $\mathrm{C}$ pathway reducing GLN uptake and cell proliferation $(53,54)$. Several phosphorylation sites exist on PPAR $\gamma$ domains and notably for PKC (55). It is therefore likely that GLN may also modify the phosphorylation process of PPAR $\gamma$.

Collectively, our results demonstrate that GLN-depleted serum is useful when investigating the impact of GLN on PPAR $\gamma$ expression. However, we demonstrated that in differentiating Caco-2 cells, PPAR $\gamma$ expression is modulated differently depending on the GLN concentrations added to the medium.

\section{Acknowledgements}

We are grateful to A. Beltz and E. Brunner for technical assistance. This work was supported by grants from La Ligue contre le Cancer, Comité National, Comité de Moselle et Meurthe-et-Moselle and CIRC-CHRU Nancy. 


\section{References}

1. Michalik L, Desvergne B and Wahli W: Peroxisomeproliferator-activated receptors and cancers: complex stories. Nature Rev 4: 61-70, 2004.

2. Huin C, Schohn H, Hatier R, et al: Expression of peroxisome proliferator-activated receptors (PPARs) in differentiating human colon adenocarcinoma Caco-2. Biol Cell 94: 15-27, 2002.

3. Lefebvre M, Paulweber B, Fajas L, Woods J, McCrary C, Colombel JF, Najib J, Fruchart JC, Datz C, Vidal H, Desreumaux P and Auwerx J: Peroxisome proliferator-activated receptor gamma is induced during differentiation of colon epithelium cells. J Endocrinol 162: 331-340, 1999.

4. Mansen A, Guardioladiaz H, Rafter J, Branting C and Gustafsson JA: Expression of the peroxisome proliferatoractivated receptor (PPAR) in the mouse colonic mucosa. Biochem Biophys Res Commun 222: 844-851, 1996.

5. Drori S, Girnun GD, Tou L, et al: Hic-5 regulates an epithelial program mediated by PPARgamma. Genes Dev 19: 362-375, 2005.

6. Koeffler HP: Peroxisome proliferator-activated receptor gamma and cancers. Clin Cancer Res 9: 1-9, 2003.

7. Lefebvre AM, Chen I, Desreumaux P, et al: Activation of the peroxisomes proliferator-activated receptor gamma promotes the development of colon tumors in C57BL/6J-APCMin/+mice. Nat Med 4: 1053-1057, 1998.

8. Saez E, Tontonoz P, Nelson MC, et al: Activators of the nuclear receptor PPARgamma enhance colon polyp formation. Nat Med 4: 1058-1061, 1998.

9. Van Eijk HM, Dejong CH, Deutz NE and Soeters PB: Influence of storage conditions on normal plasma amino-acid concentrations. Clin Nutr 13: 374-380, 1994.

10. van der Hulst R, Meyernfeldt MV and Soeters P: Glutamine: an essential amino acid for the gut. Nutrition 12: S78-S81, 1996

11. Perez-Gomez C, Mates JM, Gomez-Fabre PM, del CastilloOlivares A, Alonso FJ and Marquez J: Genomic organization and transcriptional analysis of the human L-glutaminase gene. Biochem J 370: 771-784, 2003.

12. Porter LD, Ibrahim H, Taylor L and Curthoys NP: Complexity and species variation of the kidney-type glutaminase gene. Physiol Genomics 9: 157-166, 2002.

13. Turner A and McGivan JD: Glutaminase isoform expression in cell lines derived from human colorectal adenomas and carcinomas. Biochem J 370: 403-408, 2003.

14. Souba W: Glutamine and cancer. Ann Surg 218: 715-728, 1993.

15. Windmueller $\mathrm{H}$, and Spaeth $\mathrm{A}$ : Uptake and metabolism of plasma glutamine by the small intestine. J Biol Chem 249: 5070-5079, 1974.

16. Sheppard W: Effects of short-chains fatty-acids on gut morphology and function. Gut 35: S35-S38, 1994.

17. Rhoads J, Argenzio R, Chen W, et al: L-Glutamine stimulates intestinal cell proliferation and activates mitogen-activated protein kinases. Am J Physiol 272: G943-G953, 1997.

18. Wiren M, Magnusson $\mathrm{K}$ and Larsson $\mathrm{J}$ : The role of glutamine, serum and energy factors in growth of enterocyte-like cell lines. Int J Biochem Cell Biol 30: 1331-1336, 1998.

19. Turowski G, Rashid Z, Hong F, Madri J and Basson M: Glutamine modulates phenotype and stimulates proliferation in human colon cancer cell lines. Cancer Res 54: 5974-5980, 1994.

20. Wachtershauser A, Loitsch S and Stein J: PPAR-gamma is selectively upregulated in Caco- 2 cells by butyrate. Biochem Biophys Res Commun 272: 380-385, 2000.

21. Ulrich S, Wachtershauser A, Loitsch S, von Knethen A, Brune B and Stein J: Activation of PPARgamma is not involved in butyrate-induced epithelial cell differentiation. Exp Cell Res 310: 196-204, 2005.

22. Pinto M, Robine-Leon S, Appay MD, et al: Enterocyte-like differentiation and polarization of the human colon carcinoma cell line Caco-2 in culture. Biol Cell 47: 323-330, 1983.

23. Huin C, Coriveau N, Bianchi A, et al: Differential expression of peroxisome proliferator-activated receptors (PPARs) in the developing human fetal digestive tract. J Histochem Cytochem 48: 603-611, 2000.

24. Bradford $M$ : A rapid and sensitive method for the quantitation of microgram quantities of protein utilizing the principal of protein-dye binding. Anal Biochem 72: 248-254, 1976.

25. Collins C, Wasa M, Souba W and Abcouwer S: Determinants of glutamine dependence and utilization by normal and tumorderived breast cell lines. J Cell Physiol 176: 166-178, 1998.
26. Heini H, Gebhardt R, Brecht A and Mecke D: Purification and characterization of rat liver glutaminase. Eur J Biochem 162: 541-546, 1987.

27. Garen A and Levinthal C: A fine structure genetic and chemical study of the enzyme alkaline phosphatase of E. coli. I. Purification and characterisation of alkaline phosphatase. Biochem Biophys Acta 38: 470-483, 1960.

28. Laemmli EK: Cleavage of structural proteins during the assembly of the head of bacteriophage T4. Nature 227: 680-685, 1970 .

29. Towbin H, Staehelin T and Gordon J: Electrophoretic transfer of proteins from polyacrylamide gels to nitrocellulose sheets: procedure and some applications. Proc Natl Acad Sci USA 76: 4350-4354, 1979.

30. Fiatte C, Huin C, Bertin I, et al: Genetic analysis of peroxisome proliferator-activated receptor- $\gamma 1$ splice variants in human colon tumour-derived cell lines and colon adenocarcinoma. Int J Oncol 29: 1601-1610, 2006.

31. Chomczynski P and Sacchi N: Single-step method of RNA isolation by acid guanidium-thiocyanate-phenol-chloroform extraction. Anal Biochem 162: 156-159, 1987.

32. Dignam J, Lebovitz RM and Roeder RG: Accurate transcription initiation by RNA polymerase II in a soluble extract from isolated mammalian nuclei. Nucleic Acids Res 11: 1475-1489, 1983.

33. Collet P, Domenjoud L, Devignes MD, Murad H, Schohn H and Dauca M: The human semaphorin $6 \mathrm{~B}$ gene is down regulated by PPARs. Genomics 83: 1141-1150, 2004

34. Ziegler T, Evans M, Fernandez-Estivariz C and Jones D: Trophic and cytoprotective nutrition for intestinal adaptation, mucosal repair, and barrier function. Ann Rev Nutr 23: 229-261, 2003.

35. Papaconstantinou H, Hwang K, Rajarama S, et al: Glutamine deprivation induces apoptosis in intestinal epithelial cells. Surgery 124: 152-160, 1998

36. Chow A and Zhang R: Glutamine reduces heat shock-induced cell death in rat intestinal epithelial cells. J Nutr 1998: 1296-1301, 1998.

37. Evans M, Jones D and Ziegler T: Glutamine prevents cytokineinduced apoptosis in human colonic epithelial cells. J Nutr 133: 3065-3071, 2003.

38. James L, Lunn P, Middleton S and Elia M: Distribution of glutaminase and glutamine synthetase activities in the human gastrointestinal tract. Clin Sci 94: 313-319, 1998.

39. Goldin E, APtekar L, Siguencia J, Tsvang E, Fich A and Zimmerman J: Reduced glutamine in colonic polyps. Scand J Gastroenterol 31: 345-348, 1996.

40. Crosby MB, Svenson JL, Zhang J, Nicol CJ, Gonzalez FJ and Gilkeson GS: PPAR $\gamma$ is not necessary for synthetic PPAR $\gamma$ agonist inhibition of iNOS and Nitric Oxide. J Pharmacol Exp Ther 312: 69-76, 2004.

41. Chawla A, Barak Y, Nagy L, Liao D, Tontonoz P and Evans RM: PPAR- $\gamma$ dependent and independent effects on macrophagegene expression in lipid metabolism and inflammation. Nat Med 7: 48-52, 2001.

42. $\mathrm{Su}$ CG and Lewis JD: Antineoplastic and anti-inflammatory effects of PPAR ligands in colitis. Gastroenterology 121 1019-1021, 2001

43. Sido B, Seel C, Hochlehnert A, Breitkreutz R and Dröge W: Low intestinal glutamine level and low glutaminase activity in Crohns' disease: A rational for glutamine supplementation. Dig Dis Sci 51: 2170-2179, 2006.

44. Sato N, Moore F, Kone B, et al: Differential induction of PPAR $\gamma$ by luminal glutamine and iNOS by luminal arginine in the rodent postischemic small bowel. Am J Physiol Gastrointest Liver Physiol 290: G616-G623, 2006.

45. Sato N, Kozar R, Zou L, et al: Peroxisome proliferator-activated receptor gamma mediates protection against cyclooxygenase-2induced gut dysfunction in a rodent model of mesenteric ischemia/reperfusion. Shock 24: 462-469, 2005.

46. Chang $\mathrm{T}$ and Szabo E: Induction of differentiation and apoptosis by ligands of peroxisome proliferator-activated receptor $\gamma$ in non-small cell lung cancer. Cancer Res 60: 1129-1138, 2000.

47. Han S, Greene M, Pitts J, Wada R and Sidell N: Novel expression and function of peroxisome proliferator-activated receptor gamma (PPAR $\gamma)$ in human neuroblastoma cells. Clin Cancer Res 7: 98-104, 2001.

48. Nixon J, Kamitani H, Baek $\mathrm{S}$ and Eling T: Evaluation of eicosanoids and NSAIDs as PPAR $\gamma$ ligands in colorectal carcinoma cells. Prost Leuk Essent Fatty Acids 68: 323-330, 2003. 
49. Theocharis S, Kanelli H, Margeli EPA, Karkandaris C, Philippides $\mathrm{T}$ and Koutselinis A: Expression of peroxisome proliferator-activated receptor-gamma in non-small cell lung carcinoma: correlation with histological type and grade. Lung Cancer 36: 249-255, 2002.

50. Adams M, Reginato M, Shao D, Lazar M and Chatterjee V: Transcriptional activation by peroxisome proliferator-activated receptor $\gamma$ is inhibited by phosphorylation at a consensus mitogen-activated protein kinase site. J Biol Chem 272: 5128$5132,1997$.

51. Hu ED, Kim JB, Sarraf P and Spiegelman BM: Inhibition of adipogenesis through MAP kinase-mediated phosphorylation of PPAR gamma. Science 274: 2100-2103, 1996.
52. Rhoads J, Argenzio R, Chen W, et al: Glutamine metabolism stimulates intestinal cell MAPKs by a cAMP-inhibitable, Rafindependent mechanism. Gastroenterology 118: 90-100, 2000.

53. Bode B, Reuter N, Conroy J and Souba W: Protein kinase C regulates nutrient uptake and growth in hepatoma cells. Surgery 124: 260-265, 1998 .

54 Pawlik T, Souba W, Sweeney T and Bode B: Phorbols esters rapidly attenuate glutamine uptake and growth in human colon carcinoma cells. J Surg Res 90: 149-155, 2000.

55. Diradourian C, Girard J and Pegorier JP: Phosphorylation of PPARs: from molecular characterization to physiological relevance. Biochimie 87: 33-38, 2005. 